\title{
Examining the physical education teacher concept related metaphor perceptions of secondary school students
}

\author{
Alpaslan GORUCU1', Onur KOKSAL², Mustafa USLU³ \\ ${ }^{1}$ Faculty of Sport Sciences, Selcuk University, Konya, Turkey \\ ${ }^{2}$ Foreign Language Schools, Selcuk University, Konya, Turkey \\ ${ }^{3}$ Faculty of Vocational Education, Selcuk University, Konya, Turkey \\ This research had published at 6th International Congress on New Trends in Education Entitled as Examining The Physical Education Teacher \\ Concept Related Metaphor Perceptions of Secondary School Students. \\ Address Correspondenceto A. Gorucu, e-mail: alpgorucu@selcuk.edu.tr
}

\begin{abstract}
The purpose of the present research was to examine the perceptions of $6^{\text {th }}$ Grade students (age range: 10-13 years old) regarding their concept of the physical education teacher expressed through metaphors and to analyze these metaphors for comparison between the genders. A total of 356 students (girls=184; boys=172) participated in the study during the 2014-2015 academic year. They were from three different state schools in the province of Konya, Turkey. According to the results, the students produced 67 different metaphors related to their concept of the physical education teacher. These metaphors were grouped under seven conceptional categories, namely "someone needed, guide, motivator; authoritarian, source of amusement, confidant and rude". There were no statistically significant differences between the genders in terms of the metaphors used. The findings revealed that the metaphor method could be used meaningfully as an important data collection tool when investigating the perceptions of students regarding their concept of the physical education teacher. This method can be recommended for use in similar and further studies.
\end{abstract}

Keywords: Concept, metaphor perceptions, physical education, teacher, secondary school.

\section{INTRODUCTION}

Senemoğlu (39) defined the metaphor method as associating new knowledge with existing knowledge, or schemas, and giving meaning to new knowledge. Perry and Cooper (35) defined the metaphor method as expressing something unknown using something known. Abrams (1) stated that human beings expressed themselves by associating their lives with other beings in the nature, and used metaphors doing this. Therefore, individuals usually experience the process of associating elements in their lives with other elements (9). Metaphors enable educators to compare between two things, and associate two things through similarities and differences $(29,37)$.

Forceville (20) defined a metaphor as expressing the perception of a concept using similes. According to Forceville (20), the three main elements in using metaphors are:

- The subject of the metaphor;

- the source of the metaphor; and
- the features of the two things that are similar between the subject and the source of the metaphor.

For instance, in the metaphor "the physical education teacher is like an ocean", there is a simile between the physical education teacher and the ocean. In this simile, the 'physical education teacher' is the subject and 'ocean' is the source of the metaphor. The answer to the question, why this simile was made, is the association between the source and the subject of the metaphor. The student answered this question to express "because our physical education teacher has a vast knowledge of sports, just like the ocean".

In this way, students try to explain the objects, events, environment and life around them using various similes through metaphors by giving a word a meaning different from its own meaning $(5,6,15)$. Therefore, by means of metaphors, individuals create a strong mental mapping and modeling mechanism for their understanding and structuring their own worlds (6). 
Metaphors can be considered as emotional meanings people give to concepts. Modell (30) defines metaphors as methods that bridge between knowledge and emotions. According to Şengül et al. (42), metaphors are methods that enable comparisons between two things, drawing attention to similarities between two things, or explaining something using something else.

Teacher metaphors are the focus of the present study. The teacher metaphor is a method that is used to reveal the roles of the teachers in the classroom and what is behind the beliefs and presupposition of students and education (12). BenPeretzet al. (12), Stichert (40), Sabanet al.(38), Cerit (15), Oflaz (31) and Şengül, et al.(42) tried to define the metaphorical perceptions of students related to the concept of 'teacher', and found that students expressed their opinions related to their teachers by not using a single metaphor but using many different metaphors.

Teachers, who play a vital role in the development of a country, raising qualified manpower, maintaining peace in the society, socialization of individuals, and transferring the social culture and values to next generation, are the important elements of education, as they are responsible of regulating educational environments for students, and serve as the role model for them $(15,17)$. Physical education teachers are responsible for the qualified execution of physical education lessons, which are considered as an inseparable part of general education (19).

Students perceive their physical education teachers differently from their other teachers, and are always prone to imitating them. The difference of physical education lessons from others is that students can get out of boring classroom atmosphere, and communicate with the teachers more easily in more comfortable clothes. Accordingly, physical education teachers are mostly the first role models of students, which bear them with more responsibilities. These responsibilities require that physical teachers be very careful in communication with their students, and be more sensitive in establishing interactions with them. As stated by Martens (27) physical teachers should not only provide students with positive skills, but also act as models with their knowledge and skills necessary for achieving success in society. Physical teacher education should be guides and models for their students with their personal skills, and they also should act in accordance with their knowledge skills and experience. Teachers' having these competencies can also affect the students' perceptions of their teachers, because it is of importance that physical education teachers guide their young students, who are developing physically, socially, psychologically and mentally. In this context, defining how physical education teachers are perceived by students is significant. Explaining the concept of physical education teacher through metaphors can help us understand better what physical education teachers mean to students, and what they expect from their teachers. Therefore, provide physical education teachers will be provided with feedback on these issues. This way, teachers can make some changes to turn negative perceptions-if there are any- to positive ones. Physical education lessons can be more fun, teachers can revise their strategies and methods in the classes to make them more students oriented. Additionally, they can contribute to programs of educational institutions about how a physical education teacher should be.

The literature review didn't produce any previous studies that defined students' perceptions of physical education teachers through metaphors. However, there have been studies that defined student perceptions through different methods. Yilmaz \& Güven (47) tried to define talented students', who attend centre for science and art, perceptions of the concept of physical education teacher through "draw-write technique", and they reported that students mostly had positive perceptions. Ryan et al. (36) also conducted a study on 611 secondary school students to define their attitudes towards physical education teachers. They reported that students developed positive attitudes towards physical education teachers.

In addition, there are other studies, which tries to define students' perceptions of other teachers through metaphors. Gedikli (21), studied secondary school students' perceptions of Turkish language teachers through metaphors, and reported that students mostly have positive perceptions of Turkish language teachers. Şengül et al. (42) reported in their study on the secondary school students' metaphorical perceptions of mathematics teachers that students produced many metaphors related to mathematics teachers, and most of these were positive. Aykaç (10) tried to find out primary school students' perceptions of teacher, and also reported that students mostly produced positive metaphors. Additionally, Martinez et al. (28) and 
Achinstein \& Barrett (2) stated that students defined their teachers through many different metaphors, but they mostly defined them as friend.

A $4+4+4$ program (4 years of primary education +4 years of secondary education +4 years of high school education) was put into effect in 2012. The purpose of the present study was to determine what kinds of meanings students in Turkish secondary schools imply with their concept of the physical education teacher compared to their grade teachers in the first four years of their education. In this context, the aim was to reveal how students perceive their physical education teachers through metaphors. This may meet a need of examining the concept of the "physical education teacher" in more detail. The main problem examined was, what are the metaphorical perceptions of $6^{\text {th }}$ Grade students of the concept 'physical education teacher'? In order to solve this problem, answers to the following questions were sought:

1. What metaphors do these $6^{\text {th }}$ Grade students produce related to their concept of the 'physical education teacher'?

2. What conceptional categories underlie these metaphors related to their concept of 'physical education teacher'?

3. Do the metaphors produced by these students differ in terms of gender group?

\section{MATERIAL \&METHOD}

\section{Research method}

The present research, which was conducted to define secondary school $6^{\text {th }}$ grade students' perceptions of physical education through metaphors, adopted a combination of quantitative and qualitative design. Quantitative researches can be defined as researches, which monitor processes intended to reveal perceptions and events in their natural environment in a holistic manner (46). Qualitative studies are required to find answers to questions which are hard to express through traditional research methods (13). In the present research, one of the qualitative research models, phenomenology model, which aims at minimizing personal experiences related to a phenomenon to universal explanations. The researchers provide a holistic description, which defines the essence of these personal experiences. Phenomenological studies use various data resources, such as interviews, poems, observations and documents (16). Phenomenology design focuses on phenomena that we are aware but don't have a deep insight of. Studies that intend to define phenomena that are not completely strange to use, but also we cannot comprehend the meaning clearly provides an appropriate ground for phenomenology (46).

\section{Participants}

The work group of the present research consists of $6^{\text {th }}$ grade students, who studied at three different secondary schools in provincial centre of Konya in 2014-2015 school year. In order to create different situations related to the problem that are similar within the sample, maximum variety sampling method was adopted (13). The total of 362 students participated in the present research. The answers from 6 students were not included in the analyses, as they left some parts blanks in the form. The frequency and percentage distributions of 356 students, who participated and produced metaphors in the present research, are presented in Table 1.

Table 1. Participants according to gender.

\begin{tabular}{lcc}
\hline Gender & Frequency & Percentage (\%) \\
\hline Female & 184 & 51 \\
Male & 172 & 49 \\
Total group & 356 & 100 \\
\hline
\end{tabular}

\section{Data collection}

The interview was used as data gathering technique. The students were requested to complete the statement: "my Physical education teacher is like ... because ...". As is generally the case in metaphor studies, using of the word "like" leads to creating a simile, and the word "because" allows giving the simile meaning. No explanations were offered in order to avoid leading or influencing the response that could affect the reliability adversely during implementation. The study was conducted in a different lesson than physical education lesson, so that students could express their ideas honestly and openly, and didn't feel any pressure on them. During the process, teacher of the lesson, the researcher and the participants were present in the classroom. No interference or guidance was offered for the students, so that they can reflect on their ideas freely and objectively. The participants were provided with one lesson period to complete the study. Before the analyses, the metaphors and reasons were written as they were, without any changes.

Within qualitative research, the metaphor method facilitates clarifying complicated or sensitive 
information that has been collected (41). Saban et al. (38) state that metaphors are the most powerful mental concepts that form, guide and follow opinions on the occurrence and continuance of events.

\section{Data analysis and interpretation}

The content analysis method was adopted to analyze the data collected in the present study. The main purpose of content analysis is identifying concepts and relationships that can explain the collected data (7). The main procedures pursued in content analysis are gathering similar data in the framework of certain concepts and themes, and organizing and interpreting them in a way that the reader can understand (45). In the analysis of the data collected in the present study, four steps were followed:

1. Naming the metaphors;

2. Classifying the metaphors;

3. Creating and analyzing the categories;

4. Testing the validity and reliability of the measure.

\section{Naming the metaphors}

In this step, the metaphors created by students were transferred into an Excel table and listed in alphabetical order. During this process, the stated metaphors were examined to ensure clarity and comprehensibility. The metaphors in the forms completed by the students were encoded. Forms that did not include any metaphors or metaphors that were not explained in a meaningful way were not included for further analysis.

\section{Classifying the metaphors}

In this step, each metaphor was separated by means of "metaphor analysis" and "content analysis" techniques and was compared to other metaphors in terms of similarity and common features $(7,22,45)$. Six of the participants were eliminated at this stage. Four were eliminated because there were omissions and a further two because they did not include complete metaphors. From the 356 accepted forms, 67 metaphors were found. These metaphors were listed again, and one representative statement was determined for the metaphors with a frequency of more than one. A list of the representative metaphors was created to be used in the categorization and analysis phase.

\section{Creating and analyzing the categories}

The purpose of this phase was to examine and identify the common features of the 67 metaphors related to the physical education teacher as created by the students. Each metaphor was associated with a theme representing the perspectives of the students. The criteria used for creating categories required that they should be:

- Comprehensive;

- mutually exclusive in a way that they did not overlap each other;

- unique so that each expressed a specific idea; and

- suitable for the purpose of the study.

\section{Testing the validity and reliability}

According to Yıldırım \& Şimşek (45), the creation of the appropriate and correct categories, the arrangement of the data in these categories and consequently explaining how the researchers labeled these categories are important as measures of validity in qualitative research. Data collected in the present research were analyzed through content analysis. Content analysis is the systematic analysis of written or verbal materials. Content analysis is the process of quantifying what people say or write, through coding in accordance with open instructions. The essence of this approach is categorizing what is written and said (11). In content analysis, collected data are coded and categorized. Then themes that can explain the data in general terms, and gather codes under certain categories are found. In order to find themes, first codes are gathered and the common points between them are detected. This is a kind of thematic coding process, and refers to categorization of the collected data through codes. If the number of themes is too many, upper themes can be formed in accordance with common points between the themes (46). Finally, obtained thematic data numbers (frequency, percentage and arithmetic average) are expressed in numbers. This way, researchers can support the qualitative process with quantitative expressions. In order to define the metaphorical differences across genders, chi-square test was utilized. Chi-square test is an analysis method used to detect the relations and differences between quantitative data (14).

This procedure was followed in the present study. To establish reliability, experts in the field of study reviewed the categorized metaphors. A coding key was prepared and photocopied for 15 experts. The researchers and experts read the 
students' metaphors independently from one another and created categories related to the metaphors. As the coding keys were marked, the metaphors that were considered irrelevant by the experts were excluded. The categories created by the experts were checked and these categories were marked as "consensus" or "dissensus". If the experts created similar categories for the student metaphors, those categories were marked "consensus", and if they created different categories, those were marked as "dissensus". The following formula of Miles and Huberman (29) was applied to calculate intercoder reliability.

$$
\mathrm{P}=\mathrm{Na} \div(\mathrm{Na}+\mathrm{Nd})
$$

Where: $\mathrm{P}=$ Reliability (\%); $\mathrm{Na}=$ Consensus; $\mathrm{Nd}=$ Dissensus

\section{RESULTS}

A total of 67 physical education teacher related metaphors were created by $3566^{\text {th }}$ grade students. One single student created forty-two of these metaphors. The most frequently used metaphor was 'friend', which was used by 83 students. The physical education teacher related metaphors ultimately represented seven different conceptional categories, namely "someone needed", "guide", "motivator", "authoritarian", source of amusement", "confidant", "rude". Table 2 lists the intercoder reliability percentages of the seven categories from the highest to lowest.

Table 2. Intercoder reliability percentages of categories created.

\begin{tabular}{lc}
\hline Categories & Reliability $\%$ \\
\hline Someone needed & 91 \\
Guide & 89 \\
Motivator & 86 \\
Authoritarian & 81 \\
Source of amusement & 80 \\
Confidant & 76 \\
Rude & 71 \\
\hline
\end{tabular}

\section{Conceptional categories}

\section{Physical education teacher as "someone needed"}

In this category, students generally characterized their physical education teachers as a friend, who they need. This category also includes the most metaphors of all the categories. Where the present research is concerned, students created metaphors related to their concept of the physical education teacher by using statements like "the teachers support students, care about their students, share their problems, and make students feel comfortable."

Table 3 presents the 19 metaphors that were grouped in this category. These metaphors consist of statements produced by 250 (70\%) participants. The most repeated metaphor in this category was "friend" which was used by 83 students. Below are some statements included in this category.

I think the physical education teacher...

is like a brother, because he would be there for us if we hurt ourselves.

is like life, because he always wants the best for us.

is like a friend, because we have a lot of fun together.

is like a sibling, because I can have a heart to heart talk with him.

is like a father, because I feel close to him. anything.

is like a friend, because I can tell him

is a close friend, because he loves me a lot.

Table 3. Physical education teacher as "someone needed".

\begin{tabular}{rlrc} 
Rank & Metaphor & Frequency & Percentage \\
\hline 1 & Friend & 83 & 33.2 \\
2 & Close friend & 53 & 21.2 \\
3 & Father & 47 & 18.8 \\
4 & Brother & 22 & 8.8 \\
5 & Mother & 8 & 3.2 \\
6 & Water & 8 & 3.2 \\
7 & Life & 6 & 2.4 \\
8 & Paternal uncle & 5 & 2.0 \\
9 & Maternal uncle & 5 & 2.0 \\
10 & Sibling & 3 & 1.2 \\
11 & Family & 2 & 0.8 \\
12 & Happiness & 1 & 0.4 \\
13 & Buddy & 1 & 0.4 \\
14 & Diamond geezer & 1 & 0.4 \\
15 & Relative & 1 & 0.4 \\
16 & Life saver & 1 & 0.4 \\
17 & First aid kit & 1 & 0.4 \\
18 & Angel & 1 & 0.4 \\
19 & Companion & 1 & 0.4 \\
\hline Total & & 250 & 100
\end{tabular}

\section{Physical education teacher as a "guide"}

This category suggests that ease of communication with their physical education teacher resulted in their perception of their teacher as a guide. According to these students, their physical education teacher is a leader who tells them or makes suggestions as to what to do in real life. 
Table 4 presents the 15 metaphors in this category as created by $26(7 \%)$ students. The most repeated metaphor in this category was "trainer" that was used by 10 participants. Below are some statements included in this category.

I think the physical education teacher...

is like a trainer, because he motivates me to do different sports.

is like a shepherd, because he tells us what we should do.

is like a leader, because I do what he does and follow his lead.

is like a captain, because he leads us in games that we don't know.

is like a soldier, because he taught me everything I know about sports.

Table 4. Physical education teacher as "guide".

\begin{tabular}{clcc}
\hline Rank & Metaphor & Frequency & Percentage \\
\hline 1 & Trainer & 10 & 38.5 \\
2 & Life coach & 3 & 11.5 \\
3 & Shepherd & 1 & 3.8 \\
4 & Organizer & 1 & 3.8 \\
5 & Leader & 1 & 3.8 \\
6 & Captain & 1 & 3.8 \\
7 & Taxi driver & 1 & 3.8 \\
8 & Sports assistant & 1 & 3.8 \\
9 & Sun & 1 & 3.8 \\
10 & Book & 1 & 3.8 \\
11 & Eyes & 1 & 3.8 \\
12 & Chief & 1 & 3.8 \\
13 & Manager & 1 & 3.8 \\
14 & Wind & 1 & 3.8 \\
15 & Candle & 1 & 3.8 \\
\hline Total & & 26 & 100 \\
\hline
\end{tabular}

\section{Physical education teacher as "motivator"}

This category consists of expressions of the students who perceive the concept of physical education teacher as motivator. The students who are sportsman developed this perception because their teacher is their role model. Furthermore, the students viewed their physical education teacher as a person who energises them and instils the desire to succeed. Table 5 shows the 17 metaphors in this category and was created by $29(8 \%)$ students. The most repeated metaphor was "air" which was used by four participants. Below are some statements included in this category.

I think the physical education teacher... is like an energy drink, because he gives me strength and energy.

is like cacao, because I get motivated as I eat.

is like an enemy, because I get furious when he is angry with me.

is like an artist, because when he acts cool, I want to be like him.

Table 5. Physical education teacher as "motivator".

\begin{tabular}{clcc}
\hline Rank & Metaphor & Frequency & Percentage \\
\hline 1 & Artist & 5 & 17.2 \\
2 & Air & 4 & 13.8 \\
3 & Flower & 4 & 13.8 \\
4 & Enemy & 2 & 6.9 \\
5 & Tree & 2 & 6.9 \\
6 & Energy drink & 1 & 3.5 \\
7 & Cacao & 1 & 3.5 \\
8 & Galatasaray & 1 & 3.5 \\
9 & Pen & 1 & 3.5 \\
10 & Talent & 1 & 3.5 \\
11 & Mineral & 1 & 3.5 \\
12 & Daisy & 1 & 3.5 \\
13 & Love & 1 & 3.5 \\
14 & Tyre & 1 & 3.5 \\
15 & Footballer & 1 & 3.5 \\
16 & Ocean & 1 & 3.5 \\
17 & Inspiration & 1 & 3.5 \\
\hline Total & & 29 & 100 \\
\hline
\end{tabular}

\section{Physical education teacher as "authoritarian"}

This category consists of expressions of students who perceive the concept of physical education teacher as authoritarian. The $6^{\text {th }}$ Grade students developed this perception because their teachers give instructions during classes. According to them, their physical education teachers are prescriptive people. Table 6 shows five metaphors in this category created by eight $(2 \%)$ students. The most repeated metaphor in this category was "commander" which was used by three participants. Below are some statements included in this category.

I think the physical education teacher...

is like a stinker [disagreeable person] because he yells so much and he is very prescriptive. He didn't involve me in the football team.

is like a commander because we always do what he tells us to do.

is like a stick because when he gets angry, he beats us. 
Table 6. Physical education teacher as "authoritarian".

\begin{tabular}{clcc}
\hline Rank & Metaphor & Frequency & Percentage \\
\hline 1 & Commander & 3 & 37.5 \\
2 & Stinker & 2 & 25.0 \\
3 & Stick & 1 & 12.5 \\
4 & Saddam & 1 & 12.5 \\
5 & Organiser & 1 & 12.5 \\
Total & & 8 & 100 \\
\hline
\end{tabular}

\section{Physical education teacher as "source of} amusement"

The students perceived the physical education teacher as a source of amusement. They developed this perception because their physical education classes are freer than other classes, and therefore they have the opportunity to personally communicate and interact with their teacher more. According to them, their physical education teacher is a person who makes them laugh and think at the same time. Table 7 shows four metaphors in this category created by 20 (6\%) students. The metaphor repeated most in this category was "comedian", which was used by 16 of the participants. Below are some statements included in this category.

I think the physical education teacher...

is like a comedian because he always makes us laugh.

is like a toy because entertains me a lot.

is like a joker because when he gets angry, he atones with jokes.

Table 7. Physical education teacher as "source of amusement".

\begin{tabular}{clcc}
\hline Rank & Metaphor & Frequency & Percentage \\
\hline 1 & Comedian & 16 & 80 \\
2 & Joker & 2 & 10 \\
3 & Toy & 1 & 5 \\
4 & Kemal Sunal & 1 & 5 \\
Total & & 20 & 100 \\
\hline
\end{tabular}

\section{Physical education teacher as "confidant"}

In this category, the students perceived the physical education teacher as someone who listens to their problems, keeps their secrets and as a reliable person. These students developed this perception because they feel closer to their physical education teacher. According to them, their physical education teacher does not share their secrets with anyone else and listens to their problems. Table 8 shows four metaphors created by 12 (4\%) students.
The most repeated metaphor was "secretive" and was used by 9 participants. Here are some statements included in this category.

I think the physical education teacher... with him.

is like secretive because I can share everything

is like a well because I rely on him, and I can tell him my problems.

is like a dark room because I can tell him about my problems I have at home. He won't tell anyone.

Table 8. Physical education teacher as "confidant".

\begin{tabular}{clcc}
\hline Rank & Metaphor & Frequency & Percentage \\
\hline 1 & Secretive & 9 & 75.0 \\
2 & A well & 1 & 8.3 \\
3 & Dark room & 1 & 8.3 \\
4 & Wailing wall & 1 & 8.3 \\
Total & & 12 & 100 \\
\hline
\end{tabular}

\section{Physical education teacher as "rude"}

Table 8 shows three metaphors in the "rude" category created by 11 (3\%) students. The metaphor mentioned most in this category was "swearer" which was used by seven participants. Below are some statements included in this category.

I think the physical education teacher...

is like a swearer because he always swears.

is like my father because my father always swears like him.

is like a punk because he always flips the bird.

\begin{tabular}{clcc}
\multicolumn{4}{c}{ Table 9. Physical education teacher as "rude". } \\
\hline Rank & Metaphor & Frequency & Percentage \\
1 & Swearer & 7 & 63.6 \\
2 & Father & 3 & 27.3 \\
3 & Punk & 1 & 9.1 \\
Total & & 11 & 100
\end{tabular}

According to the findings presented in Table 10 , there isn't a significant difference between male and female students in terms of positive ideas for the concept of physical education teacher. Chisquare test conducted in accordance with the conceptual categories, there isn't a statistically significant difference between the metaphors produced by male and female students. 
Table 10. Gender: Distribution of metaphors according to conceptional category.

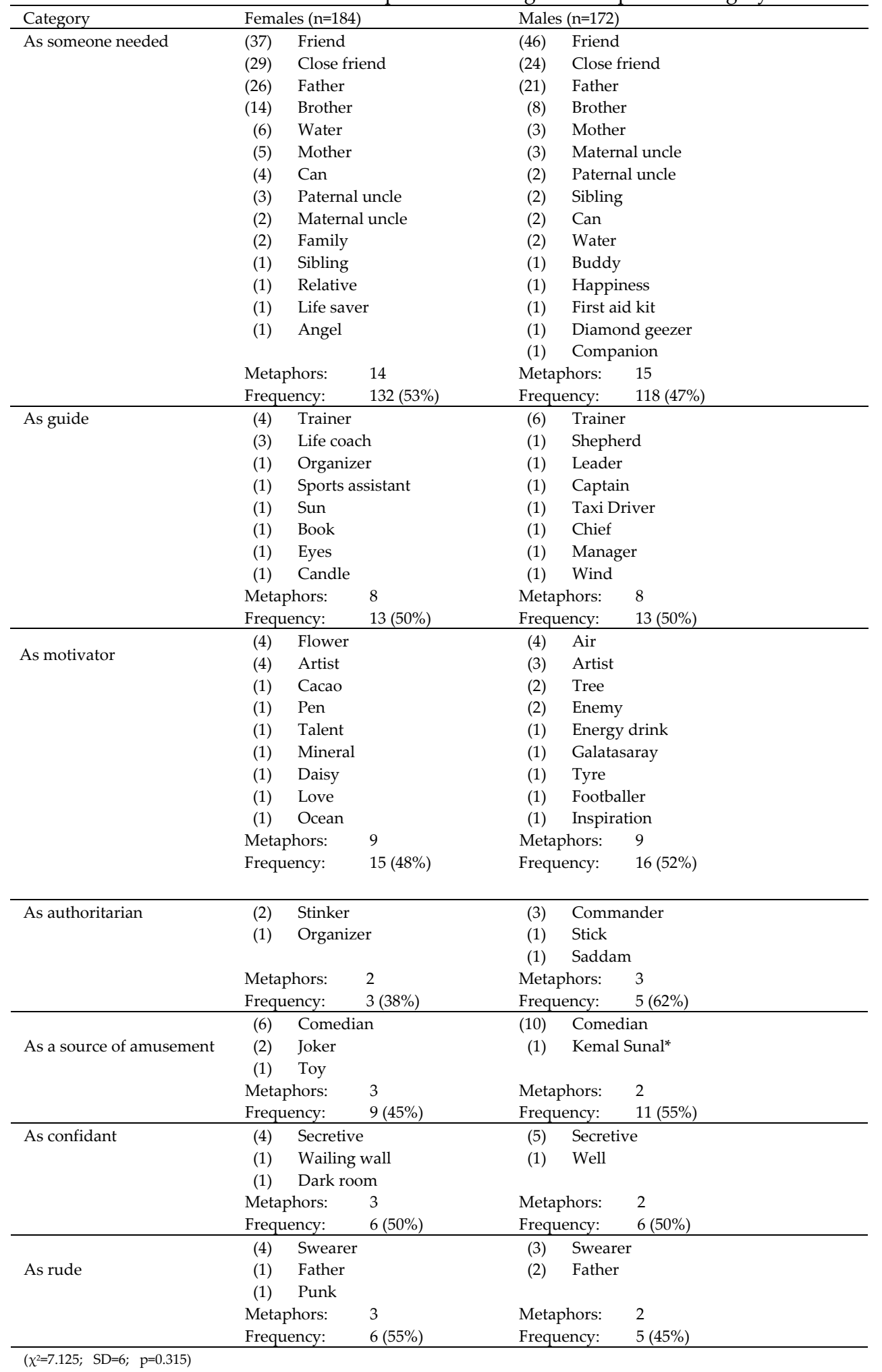

\section{DISCUSSION}

The present study, which aimed at revealing the perceptions of secondary school $6^{\text {th }}$ Grade Turkish students regarding their concept of the physical education teacher through metaphors, revealed some important issues about physical education teachers. The students produced 67 different metaphors while defining the concept of physical education teacher. This shows that they harbour different perspectives about the concept. Consequently, the large variety of metaphors suggests that it is difficult to describe the concept with one single metaphor. 
Based on the literature consulted, no research was found on this topic, which makes the present research all the more important. The present study could serve as a resource for further research on the subject matter. Of the metaphors related to the concept of the physical education teacher that was created by the students, the most frequently used metaphors were: friend 83 , close friend 53 , father 47 , comedian 16 and trainer 10 . These metaphors are an indication of why these secondary school students defined their physical education teachers using various metaphors. However, no studies have been conducted on the exact subject matter, some researchers have studied the students' perceptions the physical education teacher using different methods. Yllmaz \& Güven (47), who tried to define talented students' perceptions of the concept of physical education teacher through "draw-write technique", reported that students mostly had positive perceptions. Similarly, Ryan et al. (36) reported in their study conducted on 611 secondary school students in order to define their attitudes towards physical education teachers that students developed positive attitudes towards physical education teachers. Aybek et al. (8) also carried a descriptive study on 990 secondary school students to define their attitudes towards physical education lesson and extra-curricular activities. They found that both male and female students developed positive attitudes towards physical education teachers. The findings of these researchers are in agreement with the findings obtained in the present research.

The categories created for the perceptions of these students of the concept of the physical education teacher will be discussed. The categories that included most of the metaphors were: physical education teacher is seen as someone needed $(28 \%)$, as motivator $(25 \%)$ and as a guide $(23 \%)$. This demonstrates that the students defined their physical education teachers using positive concepts. These three categories represent $76 \%$ per cent of the students who participated in the research. Therefore, it can be concluded that these $6^{\text {th }}$ Grade students have positive attitudes towards their physical education teachers. They see their teacher as their role models and consider them as friends rather than teachers.

Neither Turkish, nor foreign literature on the subject matter include any researches on students' metaphorical perceptions of the concept of physical education teacher. However, there are some researches on metaphorical perceptions of the concept of teachers in general. Cerit (15) for example found that the concept of a teacher was not defined by one single metaphor, but students, teachers and managers defined the concept of teacher with various concepts.

Metaphor studies on this subject also present similar findings. Guerreo \& Villamil (24) and Saban et al. (38) also found that students used many various metaphors defining the concept of "teacher". Similarly, Aydın \& Pehlivan (9) reported in their research that teacher candidates used many different concepts to define the concept of "teacher". Afacan (3) found in his research on metaphorical conceptions of teacher candidates that their concept of the "science" and the "science and technology teacher" lead to many different and interesting metaphors. Şengül et al. (42) reported similar findings in their research on the metaphorical perceptions of secondary school students of their math teacher. Consequently, the findings of the present research are in agreement with those reported above.

Of the metaphors related to the concept of physical education teacher created by the $6^{\text {th }}$ Grade students in the present research, the most used metaphors were friend 83 , close friend 53 , father 47 , comedian 16 and trainer 10. These metaphors suggest that these students had positive attitudes toward the physical education teacher. It is clear that applying metaphors as a response is an effective method in determining and explaining the perceptions of these students. In the same way, negative attitudes towards physical education teachers can be detected. These can be worked on in the classroom to encourage adopting a more positive attitude.

Students are expected to feel safe and comfortable in physical education lessons. This expectation is one of the important outcomes of physical education lessons. The student metaphors 'friend', 'close friend and father', represented this expectation as found in the present study. 'Friend' and 'father' metaphors may have been because of the attention their physical education teacher paid to the personal problems of the students and the caring way students were handled which some did not experience from other teachers. Some other research $(2,28)$ also found that teachers were considered as friends. This should allow students to feel safe and comfortable at their schools (37). This kind of attention paid to the students by their teachers can 
be recommended from an educational point of view. Conceptional categories created in the present research show that students produced metaphors that referred to the friendship roles $(28 \%)$ of their physical education teachers. They stated that they feel close to their physical education teachers and that their physical education teachers care about them.

Uslu (44) stated that sports and physical education are about a set of activities that enable students to improve themselves holistically. Education plays an important part in socialization and the future development of individuals (18). Kılbaş (26) claimed that participation in games and sportive activities have socializing and guiding effects. In the present study, students produced metaphors that refer to the 'guiding' aspect (23\%) of physical education teachers. For instance, metaphors such as 'trainer', 'life coach', 'captain', 'sun' and 'candle' refer to the guiding role of physical education teachers.

Taking into account the physical, mental and cognitive differences of individuals is one of the most important issues in education. This implies that students learn in different ways, and cannot perform physical activities at the same levels due to their different psychomotor development levels. Özden (33) stated that the roles of teachers include helping, guiding, serving as a role model and encouraging students. Guiding and motivating students are among the primary responsibilities of teachers (4). Students who participated in the present research produced metaphors that referred to the motivating role of their physical education teachers (25\%). Metaphors such as 'energy drink', 'air', 'artist', and 'flower' referred to the motivating role of physical education teachers. This suggests that student-centred processes were experienced in physical education lessons.

Students also produced metaphors that referred to the 'entertaining' trait of their physical education teachers (6\%). Metaphors such as 'comedian', 'joker' and 'toy' convey the entertaining nature of their physical education teacher. This finding represents the notion that physical education teachers communicate well with their students.

This kind of communication also enables students to share their problems with their physical education teacher and to trust them. Students defined this with metaphors that referred to the 'confidant' aspect of their teachers. The metaphors used in this study were 'secretive' and 'wailing wall', which suggests the confidant aspect of the physical education teachers.

Students perceive physical education lessons as easy and entertaining $(25,32,43)$. However, physical education lessons are not only easy and entertaining, but require discipline (34). Physical education teachers have also claimed that the physical education lesson is entertaining, but they find it hard to maintain discipline during the lessons (23). Due to this, students produced some metaphors related to the 'authoritarian' aspect of their physical education teachers (8\%). This authoritarian aspect was expressed in the metaphors 'stinker' and 'stick'. Teachers sometimes have to be strict while disciplining students. Students also produced some metaphors that referred to the strict aspects of their teachers and were included in the 'rude' category such as 'swearer' and 'punk'.

Analysis of the conceptional categories in terms of gender revealed that the female students tended to have more positive thoughts about the concept of the physical education teacher than the male students did. However, no statistically significant differences between female and male students regarding the metaphors produced. This finding is in agreement with the finding of the study conducted by Şengül et al.(42).

In conclusion, the present study analyzed how students perceive the concept of physical education teacher through metaphors. In general, the students used positive metaphors to define their teachers. Physical education teachers who make students feel close to them, guide, encourage, motivate them and make physical education lessons entertaining so that students develop positive attitudes towards sports is considered to be of relevance and importance. It can be recommended that further studies be conducted where primary school and high school students are the participants.

\section{REFERENCES}

1. Abrams MH. A glossary of literary terms. San Diego, CA: Harcourt Brace College Publishers, 1999.

2. Achinstein B, Barrett A. Framing classroom context: How teachers and mentors view diverse learners and challenges of practice. Teachers College Record, 2004; 16(4); 716-746.

3. Afacan Ö. Metaphors used by elementary science teacher candidates to describe "science" and "elementary science and technology teacher". E-Journal of New World Science Academy, 2011; 6(1): 1242-1254. 
4. Alexander P, Fives $\mathrm{H}$, Buehl MM, Mulhern J. Teaching as persuasion. Teaching and Teacher Education, 2002; 18: 795813.

5. Aristo. Poetika. İstanbul, Türkiye: Remzi Kitabevi, 2008.

6. Arslan MM, Bayrakçı M. An examination of metaphorical thinking and learning from an educational view. National Education Review, 2006; 171: 100-108.

7. Ateş M, Karatepe A. The analysis of university students' perceptions towards "global warming" concept with the help of metaphors. Marmara Geographical Review, 2013; 27: 221-241.

8. Aybek A, İmamoğlu O, Taşmektepligil MY. Öğrencilerin beden eğitimi dersi ve ders dışı etkinliklerine yönelik tutumlarının değerlendirilmesi. Spor ve Performans Araştırmaları Dergisi, 2011; 2(2): 51-59.

9. Aydın İS, Pehlivan A. The metaphors that Turkish teacher candidates use concerning "teacher" and "student" concepts. Turkish Studies International Periodical for the Languages, Literature and History of Turkishor Turkic, 2010; 5(3): 818 842.

10. Aykaç N. İlköğretim öğrencilerinin resimlerinde öğretmen ve öğrenme süreci alg1sı. Eğitim ve Bilim, 2012; 37(164): 298315.

11. Balcı A. Sosyal bilimlerde araştırma: Yöntem, teknik ve ilkeler. Ankara, Türkiye: Pegem Yayıncılık, 2011.

12. Ben-Peretz M,Mendelson N, Kron FW. How teachers in different educational context view their roles. Teaching and Teacher Education, 2003; 19: 277-290.

13. Büyüköztürk Ş, Kılıç-Çakmak E, Akgün ÖE, Karadeniz Ş, Demirel F. Bilimsel araştırma yöntemleri. Ankara, Türkiye: PegemYayıncilık, 2014.

14. Can A. SPSS ile Bilimsel Araştırma Sürecinde Nicel Veri Analizi. Ankara, Türkiye: Pegem Yayıncılık, 2016.

15. Cerit Y. Students, teachers and administrators' views on metaphors with respect to the concept of teacher. Turkish Journal of Educational Sciences, 2008; 6(4): 693-712.

16. Creswell JW. Nitel Araştırma Yöntemleri (Çeviri: Bütün M \& Demir SB). Ankara, Türkiye: Siyasal Yayıncılık, 2013.

17. Çelikten M, Can N. Yönetici, öğretmen ve veli gözüyle ideal öğretmen. Selçuk Üniversitesi Eğitim Fakültesi Dergisi, 2003; 25: 253-267.

18. Demirel Ö. Eğitimde Program Geliştirme (10.Baskı). Ankara Türkiye: Pegem Yayıncılık, 2007.

19. Demirhan G. Dünyada beden eğitimi öğretmeni yetiştirme. 2. Ulusal Beden Eğitimi Öğretmenliği Sempozyumu, Bursa, Türkiye, 21-23 Aralık, 2001.

20. Forceville $C$. The identification of target and source in pictorial metaphors. Journal of Pragmatics, 2002; 34: 1-14.

21. Gedikli Ö. Ortaokul 2, 3 ve 4. sınıf öğrencilerinin Türkçe öğretmenini algılayışının metaforlar aracılığıyla belirlenmesi. Yayımlanmamış Yüksek LisansTezi, Trabzon, Türkiye: Karadeniz Teknik Üniversitesi, 2014.

22. Griffin R,Mackewn A, Moser E, VanVuren KW. Learning skills and motivation: Correlates to superior academic performance. Business Education and Accreditation, 2013 5(1): 53-65.
23. Göktaş Z. Job satisfaction of physical education teachers in Balıkesir. Niğde University Journal of Physical Education and Sport Science, 2007; 1(1): 13-26

24. Guerreo MCM, Villamil OS. Metaphorical conceptualizations of ESL teaching and learning. Language Teaching Research, 2002; 6(2): 95-120.

25. Kelinske B, Mayer BW, Chen KL. Perceived benefits from participation in sports: A gender study. Women in Management Review, 2001; 16(2): 75-84.

26. Kılbaş Ş. Rekreasyon boş zamanı değerlendirme (3. Baskı). Ankara, Türkiye: Nobel Akademik Yayıncılık, 2001.

27. Martens R. Başarılı antrenörlük (Çeviri: Büyükonat T). İstanbul, Türkiye: Beyaz Yayıncılık, 1998.

28. Martinez MA, Sauleda N, Huber GL. Metaphors as blueprints of thinking about teaching and learning. Teaching and Teacher Education, 2001; 8: 965-977.

29. Miles MB, Huberman M. Qualitative data analysis: An expanded source book (2nd ed.). Thousand Oaks, Ca: Sage, 1994.

30. Modell AH. Metaphor: The bridge between feelings and knowledge. Psychoanalytic Inquiry, 2009; 29(1): 6-11.

31. Oflaz G. Primary school students' metaphorical perceptions of "mathematics" and "mathematics teacher" concepts. Paper presented at the $2^{\text {nd }}$ International Conference on "New trends in education and their implications", Antalya, Turkey, 27-29 April, 2011.

32. Özçelik E.The role of a physical education course in the socialization of students. Unpublished master's thesis. İstanbul, Turkey: Beykent University, 2007.

33. Özden Y. New values in education. Ankara, Turkey: Pegem A Publishers, 2002

34. Özdinç Ö. The sentiments of Çukurova University students on sports and the sports participation-socialization relationship. Spormetre Journal of Physical Education and Sports, $2005 ; 3(2)$ : 77-84.

35. Perry C, Cooper M. Metaphors are good mirrors: Reflecting on change for teacher educators. Reflective Practice, 2001; 2(1): 41-52.

36. Ryan S, Fleming D, Maina M. Attitudes of middle school student toward their physical education teachers and class. Physical Educator, 2003; 60(2): 28-42.

37. Saban A. Entry level prospective classroom teachers' metaphors about the concept of "teacher". Turkish Journal of Educational Sciences, 2004; 2(2): 131-155.

38. Saban A, Koçbeker BN, Saban A. An investigation of the concept of the teacher among prospective teachers through metaphor analysis. Educational Sciences: Theory \& Practice (ESTP), 2006; 6(2): 461-522.

39. Senemoğlu, N. (2005). Development, teaching and learning: From theory to practice. Ankara, Turkey: Gazi Publishers.

40. Stichert EG. Pre-service science teachers' perception of the profession with metaphorical images and reasons for choosing teaching as a profession. Unpublished master's thesis. Ankara, Turkey: Middle East Technical University, 2005. 
41. Şahin Ş, Köksal O, Gündüz Ş. Primary and secondary school students' metaphors on technology use in foreign language education. Paper presented at the $4^{\text {th }}$ International Computer and Instructional Technologies Symposium, Konya, Turkey, April 2010, 2010.

42. Şengül S, Katranci Y, Cantimer GG. Metaphor perceptions of secondary school students about "mathematics teacher". International Journal of Social Science, 2014; 25(1): 89-111.

43. Şişko M, Demirhan G. The attitudes of male and female students from primary and secondary schools towards physical education courses. Hacettepe University Journal of the Faculty of Education, 2002; 23: 205-210.

44. Uslu S. Definition and comparison of problems, expectations of sport and physical education, of athletes attending different high schools: The sample of Zonguldak city. Unpublished master's thesis. Ankara, Turkey: Gazi University, 2005.

45. Yıldırım A, Şimşek H. Qualitative research methods in social sciences. Ankara, Turkey: Seçkin Publishers, 2006.

46. Yıldırım A, Şimşek H. Sosyal Bilimlerde Nitel Araştirma Yöntemleri. Ankara, Turkey: Seçkin Publishers, 2013.

47. Yılmaz A, Güven Ö. Üstün yetenekli öğrencilerin bedeneğitimi dersi ve beden eğitimi öğretmeni kavramlarına yönelik algılarının çizme yazma tekniği ile incelenmesi. Eğitimde Nitel Araştırmalar Dergisi-ENAD, 2015; 3(3): 55-77. 